\title{
Difference of Maternal Serum Interleukin-8 in Preterm Labor and Normal Pregnancy
}

\author{
Surya Negara $\mathrm{Kt}^{1}$, Stella Kawilarang ${ }^{2}$ \\ ${ }^{1}$ Maternal-Fetal Division, Departement of Obstetrics and Gynaecology, Medical Faculty, Udayana University, Sanglah Hospital Bali \\ ${ }^{2}$ Resident of Departement Obstetrics and Gynecology, Medical faculty,Udayana University, Sanglah Hospital Bali
}

\begin{abstract}
Objective: This study was designed to investigate the difference of maternal serum interleukin-8 (IL-8) in preterm labor and normal pregnancy, to know the cut off point of maternal serum $I L-8$ in preterm labor and normal pregnancy, and also to evaluate the relative risk of preterm labor. Methods: This study was conducted in analytical cross-sectional method within September $2010-$ May 2011. The inclusion sample was singleton pregnancy, within $28-37$ weeks gestational age, cervical dilation $\leq 2 \mathrm{~cm}$, and willing to join the study. Results: There were 65 pregnant women, with 32 case of preterm labor and 33 control case of normal pregnancy or not in labor state. The subject characteristics such as maternal age, gestational age, and gravid status were not significantly different (p > 0.05). While the mean rate of maternal IL-8 in the preterm labor was $34.98 \pm 34.79$ and the mean rate of maternal IL-8 in the normal pregnancy was $11.41 \pm 3.32$, and they were significantly different $(t=3.81$ and $p=0.001)$. Based on the analysis using ROC curve, the cut off point was $15.30 \mathrm{pg} / \mathrm{ml}$, with sensitivity $81.8 \%$ and specificity $75 \%$. Based on that cut off point, there was significant difference between IL-8 among two group, with $x^{2}=21.104$ and $p=0.001$. The relative risk of preterm labor of maternal serum IL-8 $>15.30 \mathrm{pg} / \mathrm{ml}$ was 3-4 times $(R R=3.50,95 \% C I=1.86-6.60)$. Conclusion: This study showed that there were no difference of the sample characteristics, with significant differences of IL-8 value between the two groups. In the ROC curve, the cut off point was $15.30 \mathrm{pg} / \mathrm{ml}$ with sensitivity $81.8 \%$ and specificity $75 \%$. Based on that cut off point value, the relative risk of preterm labor was $3-4$ times $(R R=$ $3.50,95 \% C I=1.86-6.60)$. It could be concluded that high maternal serum IL-8 level in preterm pregnancy could induce the spontaneous preterm labor.
\end{abstract}

Keywords: Interleukin-8, preterm labor, normal pregnancy

\section{Introduction}

Preterm labor is a crucial obstetric issue, especially in perinatology aspect, in developed and developing countries. It is acknowledged as one of the most common morbidity and mortality etiology in neonatology [1]. The incidence of preterm labor was various, and it was predicted to be 10$20 \%$ in Indonesia[2], where the incidence of preterm labor in Sanglah General Hospital Denpasar in 2003 was 11.4\%[3]

The etiology of preterm labor itself was usually not known. Some pathophysiology explains that preterm labor is related to infection inside amnion, utero-placental ischemia, overdistension of the uterus, endocrine disorders, and also abnormal immune response among the maternal or fetal. There are lots of studies that evaluate the correlation and expression of cytokines in the preterm labor. Cytokines interaction such as TNF- $\alpha$, IL-1, IL-6, IL- 8 and their activity in the metabolism of arachidonic acid plays a role in the correlation of infection and preterm labor[4].

Patients with sign and symptoms of preterm labor and premature rupture of membrane show increase of various cytokines in the maternal serum. As the result, cytokines play crucial role in the initiation of preterm labor and the premature rupture of membrane. Interaction between cytokines such as TNF- $\alpha$, IL-1 IL- 6 and IL- 8 and also their activity in the arachidonic acid metabolism, are hypothesized to play a role in the correlation between infection and preterm labor. One of the inflammation cytokines in the serum is IL- 8 . Some studies showed that high level of maternal serum IL-8 correlates with the initiation of preterm labor and premature rupture of membrane even though the result were various [5].
Many fetomaternal experts have developed studies regarding to the inflammation process in the amniotic membrane, placenta and expression of inflammation mediator such as IL-I $\beta$, IL-8, TNF- $\alpha$ for the last decade. This study was designed to evaluate the differences of maternal serum IL- 8 value in the preterm labor and normal pregnancy, to know the cut off point of IL-8 and their sensitivity and specificity, and also the relative risk of preterm labor.

\section{Materials and Methods}

This study was conducted in analytic cross sectional method, with samples were obtained consecutively for the normal pregnancy and the preterm labor case, who attended outpatient department clinic and emergency obstetric labor ward in Sanglah General Hospital Denpasar, Bali, Indonesia. Maternal serum was collected and evaluated in the Prodia Laboratory Denpasar for the IL-8, with Quantikine Human IL-8 Assay. This study was conducted in September 2010 May 2011. Pregnant women with premature rupture of membrane, antepartum bleeding, maternal disease, congenital anomaly of the fetus, history of operative surgery in the cervix, multiple pregnancy, polyhydramnion and history of sexual intercourse within last 24 hours were excluded from this study.

The collected data was analyzed with Statistical Package for Social Sciences (SPSS) version 10.0, and the statistic test was using $\mathrm{T}$-independent test with $\alpha=0.05$. Then with using ROC curve, the cut off point of maternal serum IL-8 was determined and also for their sensitivity and specificity. The relative risk of preterm labor was obtained by using the chi square test. 


\section{International Journal of Science and Research (IJSR) \\ ISSN (Online): 2319-7064}

Index Copernicus Value (2015): 78.96 | Impact Factor (2015): 6.391

\section{Results}

There were 65 samples collected during September 2010 May 2011, and maternal serum IL-8 were collected and analyzed in Prodia Laboratory Denpasar. There were 2 groups, which were 32 pregnant women with preterm labor and 33 pregnant women who were not in labor state or categorized in control group.

Table 1: Sample characteristics between two groups

\begin{tabular}{|c|c|c|c|}
\hline Variable & $\begin{array}{c}\text { Preterm labor } \\
(\mathrm{n}=32)\end{array}$ & $\begin{array}{c}\text { Preterm normal } \\
\text { pregnancy }(\mathrm{n}=33)\end{array}$ & $\mathrm{P}$ \\
\hline Maternal age (years old $)$ & $28.00 \pm 3.95$ & $27.00 \pm 3.54$ & 0.286 \\
\hline Gestational age (weeks) & $33.22 \pm 1.13$ & $33.36 \pm 1.69$ & 0.685 \\
\hline Gravid status & $1.59 \pm 0.62$ & $1.70 \pm 0.64$ & 0.509 \\
\hline
\end{tabular}

Table 1 shows the mean of maternal age from preterm labor was 28.00, while the mean of maternal age from control group was 27.00. The mean maternal age of preterm labor group was higher than normal pregnant women, however the difference was not significant $(\mathrm{p}>0.05)$. The other sample characteristic such as gestational age and gravid status were also not significantly different $(p>0.05)$ between the two groups. As the result, all maternal subject characteristics between two groups were not significantly different.

Table 2: Mean maternal serum IL-8 between preterm labor and normal preterm pregnancy

\begin{tabular}{|c|c|c|c|c|c|}
\hline Subject group & $\mathrm{N}$ & $\begin{array}{c}\text { Mean maternal } \\
\text { IL-8 value }\end{array}$ & $\mathrm{SD}$ & $\mathrm{t}$ & $\mathrm{p}$ \\
\hline Preterm labor & 32 & 34.98 & 34.79 & \multirow{2}{*}{3.81} & 0.001 \\
\hline $\begin{array}{c}\text { Normal preterm } \\
\text { pregnancy }\end{array}$ & 33 & 11.41 & 3.32 & 3.81 & \\
\hline
\end{tabular}

Table 2 shows that the mean maternal serum IL-8 value in preterm labor was $34.98 \pm 34.79$ and the mean maternal serum IL- 8 value in the normal preterm pregnancy was $11.41 \pm 3.32$. Based on the $t$-independent test, the result was $\mathrm{t}=3.81$ with $\mathrm{p}=0.001$, and it means that the mean maternal serum IL- 8 value was significantly different $(p<0.05)$. Based on the ROC curve, the cut off point was $15.30 \mathrm{pg} / \mathrm{ml}$, with sensitivity $81.8 \%$ and specificity was $75 \%$ as it was shown in the Figure 1 below.

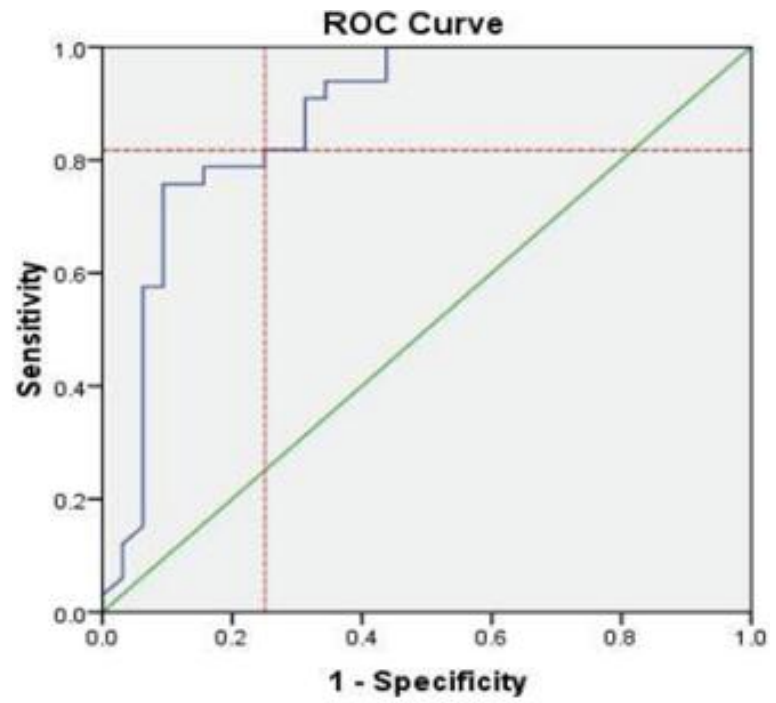

Figure 1: Receiver Operator Characteristic (ROC) curve of IL-8 value
Based on that cut off point of maternal serum IL-8, then a new set of data was categorized based on the cut off point value which was $15.30 \mathrm{pg} / \mathrm{ml}$, as shown in the Table .3 below.

Table 3: Maternal serum IL-8 proportion in preterm labor and normal preterm pregnancy

\begin{tabular}{|c|c|c|c|c|}
\hline & & $\begin{array}{c}\text { Preterm } \\
\text { labor }\end{array}$ & $\begin{array}{c}\text { Normal preterm } \\
\text { pregnancy }\end{array}$ & Total \\
\hline \multirow{2}{*}{$\begin{array}{c}\text { IL-8 } \\
\text { value }\end{array}$} & $>15.3 \mathrm{pg} / \mathrm{ml}$ & 24 & 6 & 30 \\
\hline & $<15.3 \mathrm{pg} / \mathrm{ml}$ & 8 & 27 & 35 \\
\hline & Total & 32 & 33 & 65 \\
\hline
\end{tabular}

Table 3 shows that there were 30 cases of IL- $8>15.30$ $\mathrm{pg} / \mathrm{ml}$, where 24 cases $(75 \%)$ were in the preterm labor group and $6(18.18 \%)$ were in the normal pregnancy group. Then there were 35 cases of IL- $8<15.30 \mathrm{pg} / \mathrm{ml}$, where 8 cases $(25 \%)$ in the preterm labor group and 27 cases $(81.82 \%)$ were in the normal pregnancy group. Chisquare test shows significant difference between maternal serum IL- 8 value between two groups with $\mathrm{x}^{2}=21.104$ and $\mathrm{p}$ value $=0.001$.

Table 4: Relative risk of preterm labor

\begin{tabular}{|l|l|l|l|}
\hline & \multirow{2}{*}{ RR value } & \multicolumn{2}{|c|}{ 95\% CI } \\
\cline { 3 - 4 } & & Lower limit & Upper limit \\
\hline IL-8 value > 15.30 & 3.50 & 1.86 & 6.60 \\
\hline & & & \\
\hline
\end{tabular}

Based on the cut off point of $15.30 \mathrm{pg} / \mathrm{ml}$, it shows that the relative risk of preterm labor with IL-8 $>15.30 \mathrm{pg} / \mathrm{ml}$ was 3 4 times $(\mathrm{RR}=3.50,95 \% \mathrm{CI}=1.86-6.60)$

\section{Discussion}

Preterm labor is a crucial obstetric issue, especially in perinatology aspect, in developed and developing countries. It is acknowledge as one of the most common morbidity and mortality etiology in neonatology. There was approximately $75 \%$ neonatal mortality caused by preterm babies [1].

Many theories try to explain the pathophysiology of preterm labor with infection, ischemia and respond of inflammation in the chorioamnion and decidual tissue. It was also found that $70-80 \%$ spontaneous preterm labor was having significant correlation with infection in the vagina and cervix [6].

Infection or inflammation within maternal circulation or intrauterine will trigger the release of substance such as bacterial endotoxin (lipopolysaccharides) into amniotic fluid. As the result, decidual tissue will produce cytokines and prostaglandin that induce labor, such as IL-1, TNF, IL-6 and IL-8. Cytokines concentration in the amniotic fluid will increase within 9 hours after infection, and prostaglandin E2 and F2 $\alpha$ will be produced to induce uterus contraction [7].

One of the inflammation cytokines that show any acute inflammation process is IL-8. Interleukin-8 or neutrophil activating peptide- 1 is a cytokine that selectively trigger the activity of neutrophil chemotactic factor. It does not trigger the formation of prostaglandin within intrauterine tissue, but the stimulation effect is very potential just like the other cytokines such as IL-1. Interleukin-8 will induce neutrophil 


\section{International Journal of Science and Research (IJSR) \\ ISSN (Online): 2319-7064}

Index Copernicus Value (2015): 78.96 | Impact Factor (2015): 6.391

and fibroblast in the cervix to trigger the synthesis and collagenase release, as the result the level of collagen within the cervix will decrease and the cervix will be soften. This mechanism will finally cause the dilation and effacement of the cervix.

This study shows that mean maternal serum IL-8 in the preterm labor was $34.98 \pm 34.79$ and for the normal preterm pregnancy was $11.41 \pm 3.32$, with $\mathrm{t}$-independent test shows significant difference $(\mathrm{p}<0.05)$ with $\mathrm{t}=3.81$ and $\mathrm{p}=0.001$. Similar result also obtained in another study by Nakamura in Japan, that shows the increase of IL-8 value in the preterm labor compared to normal preterm pregnancy [8]. It was also proved in study by Yuichiro Tanaka[9] and also Marek Novak[10]. Both studies show that preterm labor had higher level of IL-8 compared to normal preterm pregnancy.

Based on the ROC curve, the cut off point was $15.30 \mathrm{pg} / \mathrm{ml}$ with sensitivity $81.8 \%$ and specificity $75 \%$. In the ROC curve, the value of $15.30 \mathrm{pg} / \mathrm{ml}$ lies in the left upper position of the diagonal line, which means that the prediction value was significant.

With using the cut off point of $15.30 \mathrm{pg} / \mathrm{ml}$, there were 30 cases of IL-8>15.30 pg/ml, where 24 cases $(75 \%)$ were in the preterm labor group and $6(18.18 \%)$ were in the normal pregnancy group. Then there were 35 cases of IL- $8<15.30$ $\mathrm{pg} / \mathrm{ml}$, where 8 cases $(25 \%)$ in the preterm labor group and 27 cases $(81.82 \%)$ were in the normal pregnancy group. Chisquare test shows significant difference between maternal serum IL- 8 value between two groups with $\mathrm{x}^{2}=21.104$ and $\mathrm{p}$ value $=0.001$. This study also shows the relative risk of preterm labor was 3-4 times $(\mathrm{RR}=3.50,95 \% \mathrm{CI}=1.86-$ $6.60)$. As the result, it could be concluded that the increasing level of IL-8 in the preterm gestational weeks, can increase the risk of preterm labor. However, it still could not be evaluated the period or timing of the preterm labor that will occur.

The evaluation of IL-8 using the amniotic fluid can give better illustration about the infection that causing preterm labor, but it needs amniocentesis procedure which is more invasive. Study by Bo Jacobsson in 2005 shows that high level of IL-6 and IL-8 in the cervical fluid and amniotic fluid correlate with the invasion of microbes into the chorion and amnion during preterm labor [11].

Based on this study, the increasing value of maternal serum IL-8 still could not be used as the marker of asymptomatic intrauterine infection. As the result, further examination for IL-8 sample other than maternal serum should be conducted in order to evaluate any intrauterine infection and chorioamnionitis, such as from the cervical fluid, amniotic fluid, umbilical cord, amniotic membrane and placenta. Another study can also be conducted in order to know the outcome of the baby, whether perinatal infection can also contribute to perinatal morbidity and mortality.

\section{Conclusion}

The subject characteristics of preterm labor and normal preterm pregnancy in this study were not significantly different $(p>0.05)$. The maternal serum IL-8 I preterm labor is higher and significantly different compared to the maternal serum IL-8 in the normal preterm pregnancy $(\mathrm{p}<0.005)$. Based on the ROC curve, the cut off point was found to be $15.30 \mathrm{pg} / \mathrm{ml}$, with sensitivity $81.8 \%$ and specificity $75 \%$, and it was found the relative risk was 3-4 times to be in preterm labor $(\mathrm{RR}=3.50,95 \% \mathrm{CI}=1.86-$ 6.60). Based on this study, it could be concluded that the increasing maternal serum IL-8 value in the preterm pregnancy increase the risk of spontaneous preterm labor.

\section{Conflict of Interest}

The authors declare no conflict of interest.

\section{References}

[1] Blencowe $H$, Cousens $S$, Oestergaard M, Chou D, Moller AB, Narwal R, Adler A, Garcia CV, Rohde S, Say L, Lawn JE. National, regional and worldwide estimates of preterm birth. The Lancet, June 2012. 9;379(9832):2162-72. Estimates from 2010.

[2] The SEA-ORCHID Study Group (2008) Correction: Use of Evidence-Based Practices in Pregnancy and Childbirth: South East Asia Optimising Reproductive and Child Health in Developing Countries Project. PLOS ONE 3(7): 10.1371/annotation/f3fa6c7e-2d8b423b-824b-0373dee3c86c.

[3] Udiarta \& Swardewa, T.G.A.(2004) Profil Persalinan Preterm di RS Sanglah Periode Januari 2001 sampai Desember 2003. Lab/SMF Obstetri Ginekologi RS Sanglah Denpasar.

[4] Peltier MR. Immunology of term and preterm labor. Reprod Biol Endocrinol. 2003; 1: 122. doi: 1.1186/1477-7827-1-122

[5] Sozmen, S., Mungan, T., Micozkadioglu, S.D. \& Tapisiz, L.O.( 2005), "Predictive Value of Maternal serum and Vaginal Interleukin-6 Level in Preterm Labor", J Soc Gynecol Investig, vol.12, no. 4, pp.1-6.

[6] Kataoka S, Yamada T, Chou K, Nishida R, Morikawa M, Minami M, Yamada H, Sakuragi N, Minakami H. Association between Preterm Birth and Vaginal Colonization by Mycoplasmas in Early Pregnancy. J. Clin. Microbiol. January 2006vol. 44 no. 1 51- 55

[7] Baratawidjaja, K.G. (2002), Imunologi Dasar, Edisi kelima, Balai Penerbit Fakultas Kedokteran Universitas Indonesia, Jakarta.

[8] Hasegawa-Nakamura K, Tateishi F, Nakamura T, Nakajima Y, Kawamata K, Douchi T, Hatae M, Noguchi $\mathrm{K}$. The possible mechanism of preterm birth associated with periodontopathic Porphyromonas gingivalis. J Periodont Res 2011; 46; 497-504.

[9] Yuichiro T, Hisashi N, et al (1998)," Interleukin-1 $\beta$ and interleukin-8 in cervicovaginal fluid during pregnancy," Am J Obstet Gynecol,vol.179,pp.644-9.

[10] Nowak M, Oszukowski P, Jaczewski B, Wierzbicka E, Wilczynski JR, Szpakowski A, Czichos E, Maafiej E, Szpakowski M. Maternal serum pro-inflammatory cytokines in pregnancy, labor and chorioamnionitis. Archives of Perinatal Medicine 8(4), 28-30, 2002.

[11] Bo Jacobson, Inger MB,et al,(2005),'Interleukin-6 and interleukin-8 in cervical and amniotic fluid: relationship to microbial invasion of the chorioamniotic membranes", International Journal of Obstetrics and gynaecology, vol.112, pp.719-724.

\section{Volume 6 Issue 7, July 2017 www.ijsr.net}

